\title{
SHARING ECONOMY IN PEOPLE, PROCESS AND TECHNOLOGY PERSPECTIVE : A SYSTEMATIC LITERATURE REVIEW
}

\author{
Ratna Sari \\ Computer Science Department, BINUS Graduated Program-Doctor of Computer Science, \\ Bina Nusantara University, Jakarta 11480, Indonesia \\ Information Systems Department, School of Information Systems, Bina Nusantara University, \\ Jakarta 11480, Indonesia

\section{Meyliana*} \\ Information Systems Department, School of Information Systems, Bina Nusantara University, \\ Jakarta 11480, Indonesia \\ Achmad Nizar Hidayanto \\ Faculty of Computer Science, Universitas Indonesia, Depok 16424, Indonesia

\section{Harjanto Prabowo} \\ Information Systems Department, School of Information Systems, Bina Nusantara University, \\ Jakarta 11480, Indonesia \\ Management Department, BINUS Business School Undergraduated Program, Bina Nusantara \\ University, Jakarta 11480, Indonesia \\ *corresponding author
}

\begin{abstract}
Currently a new economic development era has occurred, starting from the concept of sharing, sharing economy becomes a phenomenon in this era. This concept also, developed an early concept of new economy that initiates change through sharing even without ownership. An important factor in sharing economy is cooperation between the service providers, service users and companies whom provide applications include with method of profit and earning allocation which able to measure company feasibility and effectiveness. Sharing economy considered with many advantages, not only able to share but also provide benefits for company and consumer. Using people, process and technology perspective, this research describes sharing economy model more systematically. The purpose of this study aims to see and describe the model of sharing economy with people, process and technology perspective by gain deeper understanding of the concept. Furthermore, this research expected able to contribute and observe related to the industry, whom adopting the concept of sharing economy. This research method used Systematic Literature Review by founded study using the specific keyword
\end{abstract}


from previous research. From 30 selected papers, this research's result there are 5 variables of sharing economy model adopted from people, process, technology: (1)Community; (2)Networking; (3)Access Ownership, (4)Platforms, (5)Payment Systems

Keyword: sharing economy, collaborative, people-process-technology, systematic literature review, framework

Cite this Article: Sari, Meyliana, Achmad Nizar Hidayanto and Harjanto Prabowo, Sharing Economy in People, Process and Technology Perspective: a Systematic Literature Review, International Journal of Management, 10 (2), 2019, pp. 100-116. http://iaeme.com/Home/issue/IJM?Volume=10\&Issue $=2$

\section{INTRODUCTION}

"Sharing" means own or use something at the same time; share with two or more unknown persons nor strangers even have relationships which the concept was changed who allows others to use without possession but still possess with same ownership rights; engage and take responsibility for use and the ownership [1]. From that understanding, the previous research said sharing is a concept that has been started since the beginning where this concept became a phenomenon for digital economy in the Internet era [2].

Jakarta, the capital city of Indonesia, is an eyewitness to the rapid development of this new economy concept, whom without ownership, but still enjoys the benefits and has the right to consume [3]. One of popular sharing economy research came from transportation development, which started from UBER in 2009 able to arousing passion of new economic concept by having authorized to consume without changing the ownership [4]. This concept consider flexsibility for the customer nor service users by using apps platform which being e-marketplace for the driver as service provider and also customer as service user [5].

From those explanation, eventually developed an early concept of a new economy and also initiated a simple concept through the sharing of ownership or better known as collaborative (sharing) economy [6]. Sharing Economy is an option for self-ownership that is emphasized where two or more individuals can enjoy the benefits (or costs) come from owning something. No longer "I" or "yours" property but seeing something as "belongs to us" [1]. Another previous research said this concept also know as online peer to peer; economic transaction between individuals vs individuals, company vs individual and company who act as supporting service platforms [7].

In sharing economy previous research, company almost never have the asset ownership but still able gain the benefits nor profit which based on ability of company to provide convenience in obtained with the main characteristics: 1) they have temporary access, non-ownership in the use of products and services; 2) integrated with internet, especially web 2.0 access [8].

The main factor in sharing economy is collaboration and teamwork between customer, company as applicaton platform provider which profit allocation able to measure the feasibility and effectiveness in the company also able to analyze the progress of its feasibility [9], from this point needs detail explanation through the comprehension of sharing economy concept and model applied in sharing economy nowdays.

According to explanation above, this research question wants to be answered is what are factors related to sharing economy in people, process, technology perspective?

As we know this research is currently new but every year become popular topic and interesting to discuss. Starting from model and the factors in sharing economy concept between consumer, company as technology provider bridges nor connector. Different country, different 
concept and the model sharing economy is not standardized. The model developed based on government regulations, therefore this research purpose aims :

- Deeply understanding of sharing economy concept and also sharing economy model

- Found the factors in sharing economy related with people, process, technology perspective [10]

\section{LITERATURE REVIEW}

\subsection{Sharing Economy}

The term of 'sharing' in sharing economy basically refers to use and access of human resources or assets. Everyone involved and they gets the benefits by sharing the assets they have [11].

Sharing Economy refers to peer-to-peer sharing of goods, services, and information coordinated through community based on technology services. Peer to peer means person can be consumers as well as producers for other person [12].

Another definition of sharing economy, said that "sharing economy is new type of model business, which creates the principle of sharing for resources between person nor individu through peer-to-peer services and posibble to use product nor service when they need it [13].

Table 1, shown the previous research about sharing economy concept with different definitions as well:

Table 1: The Definitions of Sharing Economy

\begin{tabular}{|c|c|}
\hline Refences & Definitions \\
\hline $\begin{array}{l}\text { Shaheen, Mallery, } \\
\text { and Kingsley } \\
\text { (2012) [14] }\end{array}$ & A model that emphasizes "access" or "sharing" instead of ownership \\
\hline Belk, (2010) [15] & $\begin{array}{l}\text { "The act and process of distributing what is ours to others for their use and the } \\
\text { act and process of receiving or taking something from others for our use" }\end{array}$ \\
\hline $\begin{array}{l}\text { Daunoriene et al } \\
\quad(2015)[16]\end{array}$ & $\begin{array}{c}\text { An alternative to private ownership that is emphasized on market exchange and } \\
\text { gift giving. }\end{array}$ \\
\hline $\begin{array}{l}\text { Bardhi \& Eckhardt, } \\
\text { (2015) [17] }\end{array}$ & $\begin{array}{l}\text { Access over ownership is the most common mode of exchange. Access over } \\
\text { ownership means that users may offer and share their goods and services to } \\
\text { other users for a limited time through peer-to peer sharing activities, such as } \\
\text { renting and lending }\end{array}$ \\
\hline $\begin{array}{c}\text { Filippas \& } \\
\text { Gramstad (2016) } \\
{[18]}\end{array}$ & $\begin{array}{l}\text { Online peer-to-peer marketplaces as platform for easier access to goods and } \\
\text { services. }\end{array}$ \\
\hline Roh (2016) [19] & $\begin{array}{l}\text { A new economic model beyond the paradigm of mass production and } \\
\text { consumption. }\end{array}$ \\
\hline Cheng (2016) [20] & $\begin{array}{l}\text { The phenomenon of peer to peer sharing of access to underutilized goods and } \\
\text { services, which prioritizes the utilization and accessibility of ownership }\end{array}$ \\
\hline $\begin{array}{l}\text { Munoz \& Cohen } \\
\quad(2017)[21]\end{array}$ & $\begin{array}{c}\text { A socio- economic system enabling an intermediated set of exchanges of goods } \\
\text { and services between individuals and organizations which aimto increase } \\
\text { efficiency and optimization of under-utilized resources in society. }\end{array}$ \\
\hline $\begin{array}{l}\text { Kumar, Lahiri \& } \\
\text { Dogan (2017) [22] }\end{array}$ & $\begin{array}{l}\text { The monetization of underutilized assets that are owned by service providers } \\
\text { (firms or individuals) through short-term rental }\end{array}$ \\
\hline $\begin{array}{l}\text { Kooti et al (2017) } \\
{[23]}\end{array}$ & $\begin{array}{l}\text { Exchange services in a peer-to-peer fashion, through match- ing markets } \\
\text { facilitated by social networks and online applications. }\end{array}$ \\
\hline $\begin{array}{l}\text { Godelnik (2017) } \\
{[24]}\end{array}$ & $\begin{array}{l}\text { A facilitation between stranger for share and utilized in reduce cost but gain } \\
\text { benefit. }\end{array}$ \\
\hline $\begin{array}{l}\text { Böcker \& Meelen, } \\
\text { (2017) [25] }\end{array}$ & $\begin{array}{l}\text { Consumers granting each other with temporary access to their under-utilized } \\
\text { physical assets ("idle capacity"), possibly for money. }\end{array}$ \\
\hline
\end{tabular}




\section{Belk, (2014) [2]}

Dividing something between relative strangers or when it is intended as a onetime act such as providing someone with spare change, directions, or the time of day.

Professor Yochai Benkler, Harvard University in his writing mention the prediction of social networking boom where each of individual would do sharing in meet their needs [26].

Previous research of sharing economy mentioned, there are some things that make this sector interested which the key elements are: shifted ownership; trend of technology; economic needs; digital native hood; convenience and opposed consumption [3],[24],[27].

Talked about the characteristics of the company who is adopting the sharing economy, mentioned with explanation like: (1) business idea "unlocking value" according to utilization of non-optimal assets for monetary or non-monetary benefits; (2) values adopted such as transparency, humanity, and authenticity for short and long term strategic decisions; (3) The providers of services are empowered as well as companies committed to making life service providers have better economic and social; (4) customers will get goods and services in a more efficient way that they pay for access but not ownership; [28].

Main benefits of sharing economy known as two ways impact for the company and individu such as: (1) Reduce the negative impact on the environment by reducing the amount to be produced that saves industrial pollution (such as reducing carbon footprint and human resource consumption); (2) Reduce production costs and enable recycling; (3) Increasing independence and flexibility; (4) Accelerate consumption patterns and sustainable production in cities around the world; (5) Improved service quality through rating system provided by users; (6) Increased flexibility of working hours and wages [8],[29],[30].

\subsection{People, Process Technology Perspective}

The successful of implementation for nowdays assosiated with people, process and technology [31]. In sharing economy, without doubt the same concept implemented and build by involving people, process and technology whom support all process and transaction [12].

Simple definition of people in sharing economy concept is person or individu who is doing sharing, without any relationship, not knowing each other but share each other [1] while, for the concept of "process" is a way to connect "people" and encourage to share by calculate the economic value and benefits for all parties [25].

Previous research mentioned as technology based. According to Böckmann, (2013) [25] one of main important factor which encourage sharing economy is technology that has helped Sharing Economy to become what is now [1].

In table 2, explained about definition people, process and technology in sharing economy based on previous research:

Table 2: The Definitions of People, Process, Technology in Sharing Economy

\begin{tabular}{|c|c|c|c|}
\hline References & People & Process & Technology \\
\hline Conte, (2016) [1] & $\begin{array}{c}\text { Can use, share, without } \\
\text { ownership. }\end{array}$ & $\begin{array}{c}\text { The way of consume, } \\
\text { engaging and joint } \\
\text { activity, focusing on } \\
\text { their interactions with } \\
\text { customers/riders. }\end{array}$ & $\begin{array}{c}\text { New kind of inter- } \\
\text { personal relationship } \\
\text { mediated }\end{array}$ \\
\hline $\begin{array}{c}\text { Banerjee, Freund, \& } \\
\text { Lykouris, (2016) [32] }\end{array}$ & $\begin{array}{c}\text { Willing to share with, } \\
\text { fullfil the needs of } \\
\text { his/herself and others. }\end{array}$ & $\begin{array}{c}\text { A systems, whom } \\
\text { customers have access } \\
\text { to a collection of } \\
\text { personal needs which } \\
\text { can be engaged } \\
\text { anytime. }\end{array}$ \\
\hline
\end{tabular}




\begin{tabular}{|c|c|c|c|}
\hline $\begin{array}{l}\text { Kumar, Lahiri, \& } \\
\text { Dogan, (2017) [22] }\end{array}$ & $\begin{array}{l}\text { Who coordinating, } \\
\text { acquisition and } \\
\text { distribution without any } \\
\text { relationship or } \\
\text { sometimes ownership. }\end{array}$ & $\begin{array}{l}\text { The process of } \\
\text { distributing what is ours } \\
\text { to others for their use } \\
\text { and the process of } \\
\text { receiving or taking } \\
\text { something from others } \\
\text { for our use. }\end{array}$ & $\begin{array}{l}\text { The digital concept of } \\
\text { UI, ease payment } \\
\text { transaction, tracking, } \\
\text { product nor service } \\
\text { availability and respond } \\
\text { time. }\end{array}$ \\
\hline Böckmann, (2013) [13] & $\begin{array}{l}\text { The needs of value } \\
\text { without belongings } \\
\text { (non ownerships) who's } \\
\text { participating in shared } \\
\text { economy. }\end{array}$ & $\begin{array}{l}\text { The measurement of } \\
\text { shared in economic way } \\
\text { and the value of } \\
\text { aquiring in shared } \\
\text { concepts. }\end{array}$ & $\begin{array}{l}\text { Facilitates peer to peer } \\
\text { transactions. }\end{array}$ \\
\hline $\begin{array}{l}\text { Böcker \& Meelen, } \\
\text { (2017) [25] }\end{array}$ & $\begin{array}{c}\text { Who participate, } \\
\text { engaged, consumption. }\end{array}$ & - & - \\
\hline Cheng (2016) [20] & $\begin{array}{l}\text { Who coordinating, } \\
\text { consumption and } \\
\text { distribution with fee } \\
\text { nor economic benefits. }\end{array}$ & $\begin{array}{l}\text { The way to encourage } \\
\text { both parties whom } \\
\text { participate in sharing } \\
\text { economy to promote, } \\
\text { create jobs. }\end{array}$ & $\begin{array}{c}\text { The facilitations and } \\
\text { enhance how to do } \\
\text { share with. }\end{array}$ \\
\hline $\begin{array}{l}\text { Munoz \& Cohen } \\
\text { (2017) [21] }\end{array}$ & $\begin{array}{l}\text { The network who } \\
\text { cannot buy but can pay } \\
\text { to who needs extra } \\
\text { income in particular } \\
\text { shared and gain benefis } \\
\text { each others. }\end{array}$ & $\begin{array}{l}\text { The model of how to } \\
\text { utilized, and connect by } \\
\text { relies on mobile } \\
\text { connectivity }\end{array}$ & $\begin{array}{l}\text { Platforms of } \\
\text { collaborations. }\end{array}$ \\
\hline
\end{tabular}

\section{METHODOLOGY}

In this study author used a comprehensive literature review methodology of previous studies on sharing economy model about the relationship between the company as service providers, vehicle owners, and user as consumer.

In this research process was divided to: (1) determine the research sources; (2) determine the keyword patterns for the search process, (3) match criteria with research objectives, data mining, and analysis of findings and answers to the research questions. The paper based on previous publication date 2009 until now. Structure of the paper complete, which means all identity (journal/conference, identity of author, etc) is mentioned in the paper.

This paper adopted people, process, technology perspective from Bruce Schneier (1999) [10] which developed the original model "The Diamond Model" from Leavitt, H. J. (1964) [33]: structure, technology, people dan task.

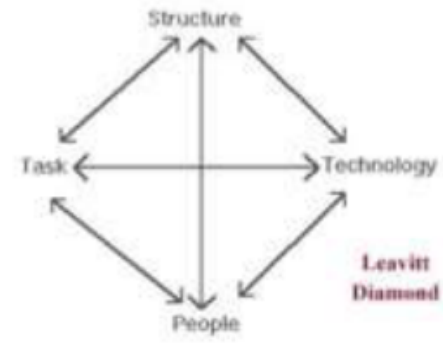

Picture 1: "Diamond Model" [33]

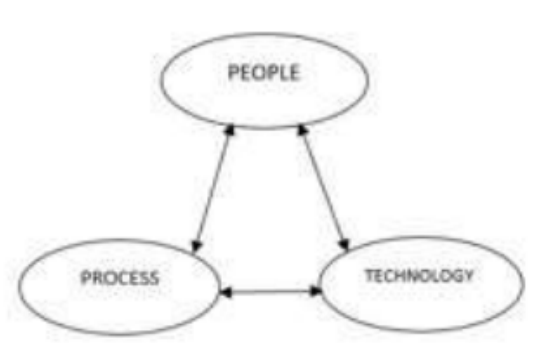

Picture 2:"People-Process-Technology" [10]

\subsection{Search Process}

In the first step, author defined the source of literature:

- ACM Digital Library (dl.acm.org) 
- IEEEXplore Digital Library (http: /ieeexplore.ieee.org)

- Science Direct (www.sciencedirect.com)

- AIS Electronic Library

The keyword used in this research is using boolean approach by filtering data, therefore author can determine the priority for data searching based on symbol used. Symbol and Boolean operator used in this research are OR, AND, and combination between OR also AND, which described below:

- "Model Sharing Economy"

- "Sharing Economy" AND "Model"

- "Sharing Economy" AND "Factor"

- "Sharing and Economy" AND "Factor Model"

- "Sharing Economy" OR "Profit Model"

- "Sharing Economy" AND "Economic Model"

- "Sharing Economy" "Model"

\subsection{Inclusion and Exclusion Criteria}

After determined the literature source as part of search process, the next step is determining which paper used in the study. In the process of determine which paper to use begins with a summary of all papers found during the search (hereinafter referred as "Founded Study")

Hereafter, the process continues by take a look at the title of paper whether accordance with the purpose of research or not. If the title is appropriate, it would continue to read the abstract, then if the title and abstract appropriate, the paper will be downloaded for further research (hereinafter referred as "Candidate Study")

From the process of "Literature Candidate" then it will be continued to read the whole paper in order to answer and fulfil the purpose of research which is perceive the whole model of sharing economy; factors in sharing economy model and the selection process of this paper will determine which appropriate papers will be used (hereinafter referred as "Selected Study")

In this study the paper used is limited from 2009 to 2017. The reason is in 2009 UBER for the first time launched and became the starting point of awakening the concept of sharing economy.

\subsection{Data Extractions}

In data extractions, author found 376 papers based on keyword used. Adapted from abstract and tiltle, there is 115 paper candidates and total 30 papers selected after reading more in both the introduction and the contents of the paper as shown in table 3:

Table 3: Data Extraction Result

\begin{tabular}{|c|c|c|c|}
\hline Source & Founded & Candidate & Selected \\
\hline ACM Digital Library & 76 & 23 & 10 \\
\hline $\begin{array}{c}\text { IEEEXplore Digital } \\
\text { Library }\end{array}$ & 46 & 15 & 5 \\
\hline Sciencedirect & 201 & 67 & 12 \\
\hline AIS Electronic Library & 53 & 10 & 3 \\
\hline Total & 376 & 115 & 30 \\
\hline
\end{tabular}




\section{RESULT AND DISCUSSIONS}

\subsection{Publishing Outlet}

\subsubsection{Publication Source}

The pattern of research according to 30 papers used, author mapping the source of paper and year of publication like seen in the table 4 . From the table 4 shown the publication according to sharing economy in 2009 - 2011 none publication for sharing economy, starting from 2012 -2015 there is only one publication each year while for year 2016 there are 12 publications consist of 8 conferences and 4 journals and in 2017, related publications sharing economy total of 14 publications, 8 journals and 6 conference:

Table 4: Publications Source: Year and Type Publication

\begin{tabular}{|c|c|c|c|}
\hline No. & Paper Title & Year & Source Type \\
\hline 1 & $\begin{array}{l}\text { Not just a taxi”"? For-profit } \\
\text { ridesharing .. [36] }\end{array}$ & 2014 & Journal \\
\hline 2 & $\begin{array}{c}\text { Pricing and Optimization in } \\
\text { Shared .. [32] }\end{array}$ & 2016 & Conference \\
\hline 3 & $\begin{array}{c}\text { Drivers, riders and service } \\
\text { providers .. [38] }\end{array}$ & 2017 & Conference \\
\hline 4 & Sharing for .. [25] & 2017 & Journal \\
\hline 5 & What's mine is yours .. [39] & 2016 & Journal \\
\hline 6 & $\begin{array}{c}\text { Exploring Sharing Economy } \\
\text { Success .. [40] }\end{array}$ & 2017 & Conference \\
\hline 7 & Dynamic Pricing .. [41] & 2016 & Conference \\
\hline 8 & Sharing economy .. [20] & 2016 & Journal \\
\hline 9 & $\begin{array}{c}\text { Evaluating Sustainability .. } \\
{[42]}\end{array}$ & 2015 & Journal \\
\hline 10 & Upsides and downsides .. [43] & 2017 & Journal \\
\hline 11 & Prices and Subsidies ..[44] & 2016 & Conference \\
\hline 12 & A Model of Pricing .. [45] & 2016 & Conference \\
\hline 13 & Millennials and .. [46] & 2017 & Journal \\
\hline 14 & Social or Financial .. [47] & 2016 & Conference \\
\hline 15 & Sharing for Profit .. [48] & 2017 & Journal \\
\hline 16 & Sharing Means .. [49] & 2017 & Conference \\
\hline 17 & Analyzing Uber's .. [50] & 2017 & Conference \\
\hline 18 & A strategic framework .. [22] & 2017 & Journal \\
\hline 19 & Research on .. [51] & 2017 & Conference \\
\hline 20 & Understanding Sharing .. [52] & 2016 & Journal \\
\hline 21 & Sharing intangibles .. [53] & 2017 & Journal \\
\hline 22 & Mapping out .. [54] & 2017 & Journal \\
\hline 23 & When sharing economy .. [55] & 2017 & Conference \\
\hline 24 & A Taxonomy of .. [56] & 2016 & Conference \\
\hline 25 & The Sharing Economy: .. [19] & 2016 & Journal \\
\hline 26 & The cost to carshare .. [57] & 2017 & Journal \\
\hline 27 & $\begin{array}{l}\text { Personal vehicle sharing .. } \\
{[58]}\end{array}$ & 2012 & Journal \\
\hline 28 & Sharing Economy in .. [59] & 2016 & Conference \\
\hline 29 & $\begin{array}{c}\text { Economics of B2C Sharing .. } \\
{[60]}\end{array}$ & 2016 & Conference \\
\hline
\end{tabular}


Sari, Meyliana, Achmad Nizar Hidayanto and Harjanto Prabowo

\begin{tabular}{|c|c|c|c|}
\hline No. & Paper Title & Year & Source Type \\
\hline 30 & The Shared Economy .. [61] & 2013 & Conference \\
\hline
\end{tabular}

Furthermore authors map the conference or journal origin from the paper as detail attached in table 5:

Table 5: Publications Source: \#Publication Name

\begin{tabular}{|c|c|c|}
\hline Publications Type & Publications Name & Total \\
\hline Journal & Springer Science & 1 \\
\hline Conference & $\begin{array}{c}\text { ACM Conference on Economics and } \\
\text { Computation }\end{array}$ & 2 \\
\hline Conference & $\begin{array}{l}\text { NetEcon "Economic of Network, } \\
\text { Systems and Computation" }\end{array}$ & 1 \\
\hline Journal & $\begin{array}{c}\text { Journal of Environmental Innovation and } \\
\text { Societal Transitions }\end{array}$ & 2 \\
\hline Journal & Computer in Human Behavior & 1 \\
\hline Conference & $\begin{array}{c}\text { Pacific Asia Conference on Information } \\
\text { Systems (PACIS) }\end{array}$ & 1 \\
\hline Journal & $\begin{array}{l}\text { International Journal of Hospitality } \\
\text { Management }\end{array}$ & 1 \\
\hline Journal & $\begin{array}{c}\text { Procedia - Social and Behavioral } \\
\text { Science }\end{array}$ & 1 \\
\hline Journal & $\begin{array}{c}\text { Journal of Technological Forecasting and } \\
\text { Social Change }\end{array}$ & 1 \\
\hline Conference & $\begin{array}{l}\text { International World Wide Web } \\
\text { Conference }\end{array}$ & 2 \\
\hline Conference & $\begin{array}{l}\text { International Conference on } \\
\text { Informations Systems (ICIS) }\end{array}$ & 3 \\
\hline Conference & $\begin{array}{c}\text { Computer Human Interaction } \\
\text { Conference }\end{array}$ & 1 \\
\hline Journal & Annals for Tourism Research & 1 \\
\hline Conference & $\begin{array}{c}\text { International ACM of Web Science } \\
\text { Conference }\end{array}$ & 1 \\
\hline Journal & $\begin{array}{c}\text { Journal of Industrial Marketing } \\
\text { Management }\end{array}$ & 1 \\
\hline Conference & $\begin{array}{c}\text { International Conference on } \\
\text { Management Engineering, Software } \\
\text { Engineering and Service Sciences } \\
\text { (ICMSS) }\end{array}$ & 1 \\
\hline Journal & Journal of Ecological Economics & 1 \\
\hline Journal & Journal of Business Research & 1 \\
\hline Journal & $\begin{array}{c}\text { Journal of Technological Forecasting and } \\
\text { Social Change }\end{array}$ & 1 \\
\hline Conference & $\begin{array}{c}\text { International Conference on Electronic } \\
\text { Governance and Open Society } \\
\text { Challenges in Eurasia }\end{array}$ & 1 \\
\hline Journal & Procedia Computer Science & 1 \\
\hline Journal & Journal of Transport Policy & 1 \\
\hline Journal & $\begin{array}{c}\text { Research in Transportation Business and } \\
\text { Management }\end{array}$ & 1 \\
\hline Conference & $\begin{array}{l}\text { Southeast Asia Computer Human } \\
\text { Interaction Symposium }\end{array}$ & 1 \\
\hline Conference & IBA Bachelor Thesis Conference & 1 \\
\hline
\end{tabular}


Sharing Economy in People, Process and Technology Perspective: a Systematic Literature Review

\begin{tabular}{|c|c|c|}
\hline Publications Type & Publications Name & Total \\
\hline Total & & 30 \\
\hline
\end{tabular}

\subsection{The Author of Papers}

\subsubsection{Profilic Authors}

From total 30 papers, there are 77 authors. Overall the author from publication writing for only one according to sharing economy, in detail shown in table 6 :

Table 6: The Author of Papers: Profilic Author

\begin{tabular}{|c|c|c|c|c|c|}
\hline Author & \# & $\%$ & Author & $\#$ & $\%$ \\
\hline Adam Wierman & 1 & $1,3 \%$ & Luca Maria Aiello & 1 & $1,3 \%$ \\
\hline Adi Tedjasaputra & 1 & $1,3 \%$ & Ludovica Principato & 1 & $1,3 \%$ \\
\hline Alice Bieszczat & 1 & $1,3 \%$ & M. Keith Chen & 1 & $1,3 \%$ \\
\hline Alina Yashina & 1 & $1,3 \%$ & Marco Böckmann & 1 & $1,3 \%$ \\
\hline Andre Hanelt & 1 & $1,3 \%$ & Mark A. Mallery & 1 & $1,3 \%$ \\
\hline Apostolos Filippas & 1 & $1,3 \%$ & $\begin{array}{l}\text { Marshall Van } \\
\text { Alstyne }\end{array}$ & 1 & $1,3 \%$ \\
\hline Arne Rogde Gramstad & 1 & $1,3 \%$ & Michael Sheldon & 1 & $1,3 \%$ \\
\hline Asta Daunoriene & 1 & $1,3 \%$ & Mihajlo Grbovic & 1 & $1,3 \%$ \\
\hline Aura Draksaite & 1 & $1,3 \%$ & Mingming Cheng & 1 & $1,3 \%$ \\
\hline Avishek Lahiri & 1 & $1,3 \%$ & Neil C.A. Lee & 1 & $1,3 \%$ \\
\hline Betine Dreyer & 1 & $1,3 \%$ & Nemanja Djuric & 1 & $1,3 \%$ \\
\hline Boyd Cohen & 1 & $1,3 \%$ & Oleg Pachenkov & 1 & $1,3 \%$ \\
\hline Cheng Kui Huang & 1 & $1,3 \%$ & $\begin{array}{c}\text { Orhan Bahadir } \\
\text { Dogan }\end{array}$ & 1 & $1,3 \%$ \\
\hline Christian Fieseler & 1 & $1,3 \%$ & Pablo Munoz & 1 & $1,3 \%$ \\
\hline Christoph Lutz & 1 & $1,3 \%$ & Päivi Kannisto & 1 & $1,3 \%$ \\
\hline Chun Der Chen & 1 & $1,3 \%$ & Peter Maas & 1 & $1,3 \%$ \\
\hline Costas Courcoubetis & 1 & $1,3 \%$ & Qing Ke & 1 & $1,3 \%$ \\
\hline Daniel Freund & 1 & $1,3 \%$ & Qun Zhao & 1 & $1,3 \%$ \\
\hline Donald N. Anderson & 1 & $1,3 \%$ & Ralph Hamann & 1 & $1,3 \%$ \\
\hline Eliane Bucher & 1 & $1,3 \%$ & Raz Godelnik & 1 & $1,3 \%$ \\
\hline Eunice Sari & 1 & $1,3 \%$ & Robert C. Nickerson & 1 & $1,3 \%$ \\
\hline Farshad Kooti & 1 & $1,3 \%$ & Saif Benjaafar & 1 & $1,3 \%$ \\
\hline Florian Lüdeke-Freund & 1 & $1,3 \%$ & Sangkeun Park & 1 & $1,3 \%$ \\
\hline Gennaro Iasevoli & 1 & $1,3 \%$ & Seunghyun Kim & 1 & $1,3 \%$ \\
\hline Gerrit Remane & 1 & $1,3 \%$ & Shuhua Li & 1 & $1,3 \%$ \\
\hline Gitana Valodkiene & 1 & $1,3 \%$ & Siddhartha Banerjee & 1 & $1,3 \%$ \\
\hline Harald Bernhard & 1 & $1,3 \%$ & Susan A. Shaheen & 1 & $1,3 \%$ \\
\hline Jan F. Tesch & 1 & $1,3 \%$ & Susik Yoon & 1 & $1,3 \%$ \\
\hline Jin Long Wang & 1 & $1,3 \%$ & Tae Hyup Roh & 1 & $1,3 \%$ \\
\hline Jiwon Jung & 1 & $1,3 \%$ & Thodoris Lykouris & 1 & $1,3 \%$ \\
\hline $\begin{array}{c}\text { Joseph P. } \\
\text { Schwieterman }\end{array}$ & 1 & $1,3 \%$ & Tiange Chen & 1 & $1,3 \%$ \\
\hline Junfeng Liao & 1 & $1,3 \%$ & Toon Meelen & 1 & $1,3 \%$ \\
\hline
\end{tabular}


Sari, Meyliana, Achmad Nizar Hidayanto and Harjanto Prabowo

\begin{tabular}{|c|c|c|c|c|c|c|}
\hline Author & $\#$ & $\%$ & & Author & $\#$ & $\%$ \\
\hline Karla J. Kingsley & 1 & $1,3 \%$ & & Uichin Lee & 1 & $1,3 \%$ \\
\hline Kristina Lerman & 1 & $1,3 \%$ & & V. Kumar & 1 & $1,3 \%$ \\
\hline Kristy Faccer & 1 & $1,3 \%$ & & Veselina Milanova & 1 & $1,3 \%$ \\
\hline Kun Pyo Lee & 1 & $1,3 \%$ & & $\begin{array}{c}\text { Vladan } \\
\text { Radosavljevic }\end{array}$ & 1 & $1,3 \%$ \\
\hline Lars Böcker & 1 & $1,3 \%$ & & Vytautas Snieska & 1 & $1,3 \%$ \\
\hline Laura Michelini & 1 & $1,3 \%$ & & Zhixuan Fang & 1 & $1,3 \%$ \\
\hline Longbo Huang & 1 & $1,3 \%$ & & & & \\
\hline Total & & $50,6 \%$ & & Total & & $49,4 \%$ \\
\hline
\end{tabular}

\subsubsection{Authors' Institutions}

From 30 papers with 77 authors, there are 49 institutions involved. The institution productively conducts research on the concept of sharing economy is University of Oslo with contribution of 2 papers and the rest of each institution contributes 1 paper with detail in table 7 :

Table 7: The Author of Papers: Authors' Institutions

\begin{tabular}{|c|c|c|}
\hline Institutions & \# & $\%$ \\
\hline Aalto University Indonesia/Finland & 1 & $2 \%$ \\
\hline Bell Laboratories & 1 & $2 \%$ \\
\hline Boston University & 1 & $2 \%$ \\
\hline California Institute of Technology & 1 & $2 \%$ \\
\hline Chaddick Institute for Metropolitan Development & 1 & $2 \%$ \\
\hline Cornell University & 1 & $2 \%$ \\
\hline DePaul University & 1 & $2 \%$ \\
\hline Duksung Women's University & 1 & $2 \%$ \\
\hline EADA Business School & 1 & $2 \%$ \\
\hline European University & 1 & $2 \%$ \\
\hline Georgia State University & 1 & $2 \%$ \\
\hline Huazhong University of Science and Technology & 1 & $2 \%$ \\
\hline Indian School of Business & 1 & $2 \%$ \\
\hline Indiana University & 1 & $2 \%$ \\
\hline Kaunas University of Technology & 1 & $2 \%$ \\
\hline Korea Advanced Institute of Sciene and Technology & 1 & $2 \%$ \\
\hline LUMSA University & 1 & $2 \%$ \\
\hline Ming Chuan University & 1 & $2 \%$ \\
\hline National Central University & 1 & $2 \%$ \\
\hline New York University & 1 & $2 \%$ \\
\hline Ningbo University & 1 & $2 \%$ \\
\hline Norwegian Business School (BI) & 1 & $2 \%$ \\
\hline Parsons School of Design & 1 & $2 \%$ \\
\hline Roma Tre University & 1 & $2 \%$ \\
\hline San Francisco State University & 1 & $2 \%$ \\
\hline School of Public Service United States & 1 & $2 \%$ \\
\hline Singapore University of Technology and Design & 1 & $2 \%$ \\
\hline South China University of Technology & 1 & $2 \%$ \\
\hline
\end{tabular}




\begin{tabular}{|c|c|c|}
\hline Institutions & $\#$ & $\%$ \\
\hline St. Petersburg State University & 1 & $2 \%$ \\
\hline Texas A\&M University & 1 & $2 \%$ \\
\hline Tilburg University & 1 & $2 \%$ \\
\hline Tsinghua University & 1 & $2 \%$ \\
\hline UCLA Anderson & 1 & $2 \%$ \\
\hline Universität Hamburg & 1 & $2 \%$ \\
\hline University of Arizona & 1 & $2 \%$ \\
\hline University of California & 1 & $2 \%$ \\
\hline University of Cape Town & 1 & $2 \%$ \\
\hline University of Chicago & 1 & $2 \%$ \\
\hline University of Göttingen & 1 & $2 \%$ \\
\hline University of Leeds & 1 & $2 \%$ \\
\hline University of Minnesota & 1 & $2 \%$ \\
\hline University of Oslo & 2 & $4 \%$ \\
\hline University of St. Gallen & 1 & $2 \%$ \\
\hline University of Technology Sydney & 1 & $2 \%$ \\
\hline University of Twente & 1 & $2 \%$ \\
\hline USC Information Sciences Institute & 1 & $2 \%$ \\
\hline Utrecht University & 1 & $2 \%$ \\
\hline UX Indonesia & 1 & $2 \%$ \\
\hline Yahoo Research & 1 & $2 \%$ \\
\hline Total & 49 & $100 \%$ \\
\hline
\end{tabular}

\subsubsection{Authors' Academic Background}

In table 8, from 77 authors there are 11 academic backgrounds. In detail, the academic background can group into big 3: Computer Science there are 24 publications, Business \& Management there are 19 publications and Information Systems there are 11 publications.

From authors' academic background, we can conclude in sharing economy is not only Business and Management domain but rather the science of Technology and Information Systems. When we talked about sharing economy the main topic almost about the applications used, how applications used for the transaction and also support the sharing economy in business concept [13].

Table 8: The Author of Papers: Authors' Academic Background

\begin{tabular}{|c|c|c|}
\hline Department & $\#$ & $\%$ \\
\hline Business \& Management & 19 & $25 \%$ \\
\hline Civil and Environmental Engineering & 1 & $1 \%$ \\
\hline Communications & 3 & $4 \%$ \\
\hline Computer Science & 24 & $31 \%$ \\
\hline Economy & 9 & $12 \%$ \\
\hline Food Technology & 1 & $1 \%$ \\
\hline Information Systems & 11 & $14 \%$ \\
\hline Public Services & 1 & $1 \%$ \\
\hline Social Sciences and Humanities & 4 & $5 \%$ \\
\hline Sociology & 2 & $3 \%$ \\
\hline
\end{tabular}




\begin{tabular}{|c|c|c|}
\hline Tourism & 2 & $3 \%$ \\
\hline Total & 77 & $100 \%$ \\
\hline
\end{tabular}

\subsection{Literature Mapping}

The next discussion, authors mapping in accordance with the concept approach Peope, Process and Technology perspective. In previous studies related to the sharing economy the initial steps of this research begin by: (1) analyzing the model of sharing economy adopted by the company; (2) comparing the whole model of sharing economy as seen the results in Table 9 below:

Table 9. Variable Classifications

\begin{tabular}{|c|c|c|c|c|}
\hline No. & Variables & Sub Variable & Component & Source Publications \\
\hline \multirow{3}{*}{1.} & People & Community & Drivers/Riders & $\begin{array}{c}\text { [43], [48], [22], [52], } \\
{[58] ;[61]}\end{array}$ \\
\hline & & & Customers & $\begin{array}{c}\text { [43]; [48]; [22]; [52]; } \\
{[58] ;[61]}\end{array}$ \\
\hline & & & Guest & {$[22] ;[52] ;[58] ;$} \\
\hline \multirow{5}{*}{2} & Process & \multirow{5}{*}{ Networking } & Lifestyle & $\begin{array}{c}{[32] ;[39] ;[40] ;[20] ;} \\
{[42] ;[47] ;[46] ;[49] ;} \\
{[51] ;[54] ;[55] ;} \\
{[59] ;[58] ;[61]}\end{array}$ \\
\hline & & & Advertise & $\begin{array}{c}\text { [40]; [22]; [51]; [52]; } \\
\text { [53]; [57]; [61]; }\end{array}$ \\
\hline & & & Branding & $\begin{array}{c}\text { [40]; [48]; [49]; [52]; } \\
{[53]}\end{array}$ \\
\hline & & & Franchising & [48]; [22]; [57] \\
\hline & & & Mobility & {$[38] ;[39] ;[20] ;[43]$} \\
\hline \multirow[t]{10}{*}{3} & Technology & $\begin{array}{c}\text { Access } \\
\text { Ownership }\end{array}$ & Licences Fee & {$[52] ;[61] ;[57]$} \\
\hline & & & Public Service & $\begin{array}{l}\text { [32]; [47]; [46]; [48]; } \\
{[49] ;[50] ;[51] ;[53] ;} \\
{[54] ;[55] ;[57] ;[58]}\end{array}$ \\
\hline & & & Assets Utilization & $\begin{array}{c}{[36] ;[38] ;[47] ;[49] ;} \\
{[51] ;[54] ;[55] ;[57] ;} \\
{[59] ;[60]}\end{array}$ \\
\hline & & Platforms & Apps Usage & $\begin{array}{c}{[38] ;[39] ;[43] ;[45] ;} \\
{[46] ;[48] ;[22] ;[52] ;} \\
{[57] ;[59] ;[61]}\end{array}$ \\
\hline & & & Apps Device & $\begin{array}{c}{[38] ;[43] ;[46] ;[45] ;} \\
{[48] ;[52] ;[60] ;[59] ;} \\
{[61]}\end{array}$ \\
\hline & & & Services Support & $\begin{array}{c}\text { [36]; [40]; [22]; [53]; } \\
{[54] ;[58]}\end{array}$ \\
\hline & & Payment Systems & Payment Gateway & $\begin{array}{c}\text { [20]; [43]; [48]; [22]; } \\
\text { [52]; [60]; [61]; }\end{array}$ \\
\hline & & & Third party revenue & $\begin{array}{c}{[20] ;[48] ;[57] ;[59] ;} \\
{[60]}\end{array}$ \\
\hline & & & Referral & {$[40] ;[48] ;[57]$} \\
\hline & & & Ventura Capital & $\begin{array}{c}{[40] ;[41] ;[52] ;[53] ;} \\
{[58] ;[61]}\end{array}$ \\
\hline
\end{tabular}




\begin{tabular}{|c|c|c|c|c|}
\hline No. & Variables & Sub Variable & Component & Source Publications \\
\hline & & & Revenue Model & {$[32] ;[36] ;[20] ;[41] ;$} \\
& & & Simmulation & {$[44] ;[48] ;[50] ;[57] ;$} \\
& & & {$[58] ;[60] ;[61]$} \\
\hline
\end{tabular}

From the description above, each sub-variables are successfully parsed describe there are components more or less have a relationship in sharing economy model development. From total of 30 selected papers, there are 5 subvariables with 19 factors approach to the sharing economy model :

\section{Community}

Community defined as a group of people who have the same needs and sometimes they also have something that can be used to meet those needs either for himself or for others [60]. Community in sharing economy as known as: consumer; driver/rider and guest which simultant provide benefits and mutual need one and other [22],[43],[48]

2. Networking

The basic concept of sharing economy is building a relationship that is connected to each other. Believe it or not networking is created when the concept of sharing economy built by the motivation to share each other by mutually beneficial and able to create a pleasant socialization between the two parties [22].

3. Access ownership

In sharing economy, ownership becomes a common thing. The important point even without ownership everyone has access that ultimately enjoys [38]. More specifically, the concept of sharing economy of asset ownership is sometimes biased because of the many perceptions of joint ownership. In his research Bucher [39] reveals that the context of sharing economy is shared, including unification and allocation of resources, the use of public property, but not contractual rent, lease or use of unauthorized properties such as theft or pseudo-sharing recognized legitimate and voluntary.

4. Platforms

Talked about platforms, it will refer to apps that serve as well as e-marketplace for every service provider, user or guest [38]. Marco Böckmann (2013) [13] mentions the platform is an innovative 'consume and collaborate' which enables users to find an easy way to meet their needs and provide benefits to other parties related to the utilization of assets with more leverage and profitable.

5. Payment systems

The ease of payment becomes much-highlighted part of the sharing economy [22]. The payment system becomes a main point not only facilitates payment but also accelerates transaction processing while maintaining a high level of security (use of credit cards or electronic balances known as digital currencies) to gain trust from users or providers [13] Furthermore, in application payment system is able to provide detailed calculations to users and service providers [2] as well as for companies providing payment system application becomes an easy tool in the process of transfer balances or payment process from users to service providers or companies to service providers and companies to the user [43]. 


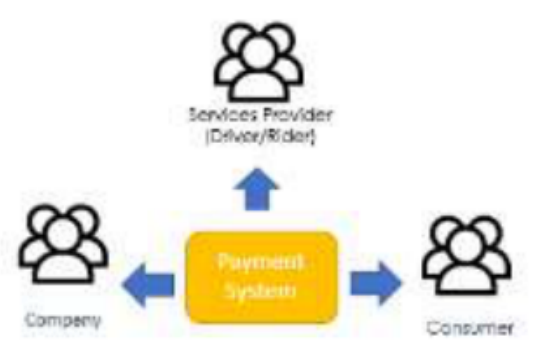

Picture 3. Flow of Payment Model

\section{CONCLUSION AND IMPLICATIONS}

From this research, author found, it can not be denied in the concept of sharing economic role of people, process and technology are interconnected. From the above it is known that the approach of people, process and technology there are $5 \mathrm{sub}$ variables which overall from the sharing economy model applied and interconnected. The concept of sharing economy "people" becomes the most important part as the main actor who can also has double role (either as asset provider or as user) the other things is "process" in sharing economy become bridge about how share doing, "The process is carefully crafted to avoid bias because of a change from "mine" to "ours". Technology perspective facilitate and support e-marketplace as a meeting place of service providers and also service users.

The implication has 2 approach for the theory and practice. For theory, it can be referenced and guided for next research about sharing economy. For the practice side, it gives contribution for application design in sharing economy used people, process and technology perspective.

\section{LIMITATION \& FUTURE RESEARCH}

The author still has limitations for the literature sources, and for future research is still possible to developed richer literature, where as discussion of sharing economy concept approach people, process and technology perspective is still not sufficient reviewed in detail.

For further research, it would be interesting to discuss related the revenue model adopted by sharing economy, it is not only talk about fixed revenue as well as the costs invested and the ability to stay competitive and make a profit. On the other hand, sharing economy model not standardized pattern associated with a good model and suitable to be implemented in Indonesia, by comparing implementation of sharing economy model will provide added value for another parties. In further research can measure with quantitative data approach related to the sharing economy model including with the pattern of customer behavior which allows better design for sharing economy model in the future.

\section{REFERENCES}

[1] Conte, C. "The Triangular Trust in the Sharing: What Trust really means in the digital sharing", Venezia, 2016.

[2] R. Belk, "You are What You Can Access : Sharing and Collaborative Consumption Online.," Journal of Business Research, pp. 1595 - 1600, 2014. https://doi.org/10.1016/j.jbusres.2013.10.001

[3] D. Provin, P. Angerer and S. Zimmermann, "Economics of B2C Sharing Platform," Thirty Seventh International Conference on Information Systems, pp. 1-9, 2016. ISBN:9780996683135

[4] C.-D. Chen, Q. Zhao, J.-L. Wang, C.-K. Huang and N. C. A. and Lee, "Exploring Sharing Economy Success: Resource-Based View and the Role of Resource Complementarity in Business Value Co-Creation," PACIS 2017 Proceedings, pp. 1-12, 2017. http://aisel.aisnet.org/pacis2017\%0Ahttp://aisel.aisnet.org/pacis2017/169 
[5] C. L. Martin, "Retrospective: compatibility management: customer-to-customer relationships in service environments.," Journal of Services Marketing, , pp. Vol.30 Iss:1, 11 - 15., 2016. https://doi.org/10.1108/JSM-10-2015-0319

[6] M. Pudhail and I. Baihaqi, "Strategi Pengembangan Ekonomi Digital," Jurnal Ilmiah Vidya, pp. Vol. 25 No. 1, 69-85., 2017.

[7] A. Filippas and A. R. Gramstad, "A Model of Pricing in the Sharing Economy: Pricing Dynamics with Awareness Generating Adoptions," Thirty Seventh International Conference on Information Systems, , 2016. ISBN: 9780996683135

[8] A. Rudenko, "The collaborative consumption on the rise: why shared economy is winning over the "capitalism of me","http://popsop.com/2013/08/the-collaborative-consumptionsharing-wins-over-ownership/, 2013

[9] D. H. Kim and K. B. Lee, "A Method of Profit Allocation for Sharing Economy among Companies Considering the Transaction Costs," Journal of the Korea Industrial Information Systems Research, pp. Vol.20 No.4: 111-126, 2015.

[10] B. Schneier, Schneier on Security, Canada: Wiley Publishing Incorporation, 1999. ISBN13: 978-0470395356

[11] V. Hendriadi, "Selamat Datang di Era Sharing Ekonomi.," 19 September 2016. [Online]. Available: http://rework.id/2016/09/19/selamat-datang-di-era-sharing-economy/ .

[12] A. J. Hamari and S. Ukkonen, "The Sharing Economy : Why People Participate in Collaborative Consumption," Journal of The Association for Information Science and Technology, 2015. https://doi.org/10.1002/asi

[13] M. Böckmann, "The Shared Economy: It is time to start caring about sharing; value creating factors in the shared economy," Ist IBA Bachelor Thesis Conf., no. June, p. 7, 2013.http://thelovettcenter.com/wp-content/uploads/2014/11/bockmann-sharedeconomy.pdf

[14] S. A. Shaheen, M. A. Mallery, and K. J. Kingsley, "Personal vehicle sharing services in North America," Res. Transp. Bus. Manag., vol. 3, pp. 71-81, 2012. https://doi.org/10.1016/j.rtbm.2012.04.005

[15] R. Belk, "Sharing," Journal of Consumer Research, pp. 715-734, 2010. https://doi.org/10.1086/612649

[16] A. Daunorienè, A. Drakšaitè, V. Snieška, and G. Valodkienè, "Evaluating Sustainability of Sharing Economy Business Models," Procedia - Soc. Behav. Sci., vol. 213, pp. 836-841, 2015. https://doi.org/10.1016/j.sbspro.2015.11.486

[17] Brady, D. (2015, July 10). The Environmental Case for The Sharing Economy. Retrieved from www.bloomberg.com.

[18] A. Filippas, L. N. Stern, and A. R. Gramstad, "A Model of Pricing in the Sharing Economy A Model of Pricing in the Sharing Economy: Pricing Dynamics with Awareness Generating Adoptions," Icis2016, no. Sundararajan 2013, pp. 1-17, 2016. https://doi.org/10.1016/j.procs.2016.07.129

[19] T. H. Roh, "The Sharing Economy: Business Cases of Social Enterprises Using Collaborative Networks," Procedia Comput. Sci., vol. 91, no. Itqm, pp. 502-511, 2016.

[20] M. Cheng, "Sharing economy: A review and agenda for future research," Int. J. Hosp. Manag., vol. 57, pp. 60-70, 2016. https://doi.org/10.1016/j.ijhm.2016.06.003

[21] P. Muñoz and B. Cohen, "Mapping out the sharing economy: A configurational approach to sharing business modeling," Technol. Forecast. Soc. Change, vol. 125, pp. 21-37, 2017. https://doi.org/10.1016/j.techfore.2017.03.035

[22] V. Kumar, A. Lahiri, and O. B. Dogan, "A strategic framework for a profitable business model in the sharing economy," Ind. Mark. Manag., no. August, pp. 0-1, 2017. https://doi.org/10.1016/j.indmarman.2017.08.021

[23] F. Kooti, M. Grbovic, L. M. Aiello, N. Djuric, V. Radosavlejevic, and K. Lerman, "Analyzing Uber's ride-sharing economy," Proc. 26th Int. Conf. World Wide Web Companion., no. January, pp. 574-582, 2017. http://dx.doi.org/10.1145/3041021.3054194 
[24] R. Godelnik, "Millennials and the sharing economy: Lessons from a "buy nothing new, share everything month' project," Environ. Innov. Soc. Transitions, vol. 23, pp. 40-52, 2017. https://doi.org/10.1108/WHATT-09-2017-0047

[25] L. Böcker and T. Meelen, "Sharing for people, planet or profit? Analysing motivations for intended sharing economy participation," Environ. Innov. Soc. Transitions, vol. 23, pp. 28 39, 2017. https://doi.org/10.1016/j.eist.2016.09.004

[26] T. Oppong, "Collaborative Consumption: The Explosive Rise of the Sharing Economy," 10 Agustus 2016. [Online]. Available: http://alltopstartups.com/2016/08/10/the-explosiverise-of-the-sharing-economy/.

[27] M. Meeker, "Internet Trends (Update)," 2012. [Online]. http://www.kpcb.com/internettrends

[28] Botsman, R. What is Collaborative Consumption and What isn't it ? Retrieved from https://www.fastcoexist.com/3046119/defining-the-sharing-economy-what-iscollaborative-consumption-and-what-isnt, 2015

[29] Parsons, A, The Sharing Economy: a Short Introduction to its political evolution. Retrieved from opendemocracy.net https:/www.opendemocracy.net/transformation/adamparsons/sharing-economy-short-introduction-to-its-politicalevolution $+\& \mathrm{~cd}=1 \& \mathrm{hl}=\mathrm{en} \& \mathrm{ct}=\mathrm{clnk} \& \mathrm{gl}=\mathrm{id}, 2015$

[30] F. Bardhi and G. M. Eckhardt, "The Sharing Economy Isnt About Sharing at All,," Harvard Business Review, 2015. https://doi.org/10.1108/14637150310496758

[31] I. J. Chen and K. Popovich, Understanding customer relationship management (CRM), vol. 9, no. 5. 2003.

[32] S. Banerjee, D. Freund, and T. Lykouris, Pricing and Optimization in Shared Vehicle Systems: An Approximation Framework. 2016. https://doi.org/10.1145/3033274.3085099

[33] H. J. Leavitt, "Applied Organization Change in Industry: structural, technical and human approaches," New Perspectives in Organization Research Journal, pp. 55-71, 1964. ISBN:0528686860 9780528686863

[34] D. N. Anderson, "'Not just a taxi'? For-profit ridesharing, driver strategies, and VMT," Transportation (Amst)., vol. 41, no. 5, pp. 1099-1117, 2014.

[35] S. Benjaafar, H. Bernhard, and C. Courcoubetis, "Drivers, riders and service providers," Proc. 12th Work. Econ. Networks, Syst. Comput. - NetEcon '17, pp. 1-6, 2017. https://doi.org/10.1145/3106723.3106724

[36] E. Bucher, C. Fieseler, and C. Lutz, "What's mine is yours (for a nominal fee) - Exploring the spectrum of utilitarian to altruistic motives for Internet-mediated sharing," Comput. Human Behav., vol. 62, pp. 316-326, 2016. https://doi.org/10.1016/j.chb.2016.04.002

[37] C.-D. Chen, Q. Zhao, J.-L. Wang, C.-K. Huang, and N. C. A. Lee, "Association for Information Systems AIS Electronic Library (AISeL) Exploring Sharing Economy Success: Resource- Based View and the Role of Resource Complementarity in Business Value CoCreation \&quot;Exploring Sharing Economy Success: Resource-Based View ," 2017.

[38] M. K. Chen and M. Sheldon, "Dynamic Pricing in a Labor Market: Surge Pricing and Flexible Work on the Uber Platform," Proc. 2016 Acm Conf. Econ. Comput., pp. 1-19, 2016. https://doi.org/10.1145/2940716.2940798

[39] A. Drakšaite, V. Snieška, and G. Valodkienè, "Evaluating Sustainability of Sharing Economy Business Models," Procedia - Soc. Behav. Sci., vol. 213, pp. 836-841, 2015.

[40] B. Dreyer, F. Lüdeke-Freund, R. Hamann, and K. Faccer, "Upsides and downsides of the sharing economy: Collaborative consumption business models' stakeholder value impacts and their relationship to context," Technol. Forecast. Soc. Change, vol. 125, pp. 87-104, 2017. https://doi.org/10.1016/j.techfore.2017.03.036

[41] Z. Fang, L. Huang, and A. Wierman, "Prices and Subsidies in the Sharing Economy," pp. 53-62, 2016. https://doi.org/10.1145/3038912.3052564

[42] A. Filippas, L. N. Stern, and A. R. Gramstad, "A Model of Pricing in the Sharing Economy A Model of Pricing in the Sharing Economy: Pricing Dynamics with Awareness Generating Adoptions," Icis2016, no. Sundararajan 2013, pp. 1-17, 2016. ISBN:9780996683135 
[43] R. Godelnik, "Millennials and the sharing economy: Lessons from a "buy nothing new, share everything month' project," Environ. Innov. Soc. Transitions, vol. 23, pp. 40-52, 2017. https://doi.org/10.1016/j.eist.2017.02.002

[44] J. Jung, S. Yoon, S. Kim, S. Park, K. Lee, and U. Lee, "Social or Financial Goals? Comparative Analysis of User Behaviors in Couchsurfing and Airbnb," CHI Ext. Abstr. Hum. Factors Comput. Syst., pp. 2857-2863, 2016.

[45] P. Kannisto, "Sharing for profit: A new business model?," Ann. Tour. Res., vol. 66, pp. 206208, 2017. https://doi.org/10.1016/j.annals.2017.07.003

[46] Q. Ke, "Sharing Means Renting?," Proc. 2017 ACM Web Sci. Conf. - WebSci '17, pp. 131139, 2017. https://doi.org/10.1145/3091478.3091504

[47] F. Kooti, M. Grbovic, L. M. Aiello, N. Djuric, V. Radosavlejevic, and K. Lerman, "Analyzing Uber's ride-sharing economy," Proc. 26th Int. Conf. World Wide Web Companion., no. January, pp. 574-582, 2017. ISBN:9781450349147

[48] J. Liao, S. Li, and T. Chen, "Research on TPB model for Participating Behavior in Sharing Economy," Proc. 2017 Int. Conf. Manag. Eng. Softw. Eng. Serv. Sci. - ICMSS '17, pp. 306310, 2017. https://doi.org/10.1145/3034950.3034999

[49] L. Michelini, L. Principato, and G. Iasevoli, "Understanding Food Sharing Models to Tackle Sustainability Challenges," Ecol. Econ., vol. 145, no. July 2016, pp. 205-217, 2018. https://doi.org/10.1016/j.ecolecon.2017.09.009

[50] V. Milanova and P. Maas, "Sharing intangibles: Uncovering individual motives for engagement in a sharing service setting," J. Bus. Res., vol. 75, pp. 159-171, 2017. https://doi.org/10.1016/j.jbusres.2017.02.002

[51] P. Muñoz and B. Cohen, "Mapping out the sharing economy: A configurational approach to sharing business modeling," Technol. Forecast. Soc. Change, vol. 125, pp. 21-37, 2017. https://doi.org/10.1016/j.techfore.2017.03.035

[52] O. Pachenkov and A. Yashina, "When sharing economy meets digital one," Proc. Int. Conf. Electron. Gov. Open Soc. Challenges Eurasia - eGose '17, pp. 91-98, 2017. https://doi.org/10.1145/3129757.3129774

[53] G. Remane, A. Hanelt, R. C. Nickerson, J. F. Tesch, and L. M. Kolbe, "A Taxonomy of Carsharing Business Models,” Int. Conf. Inf. Syst., pp. 1-19, 2016. ISBN:9780996683135

[54] J. P. Schwieterman and A. Bieszczat, "The cost to carshare: A review of the changing prices and taxation levels for carsharing in the United States 2011-2016," Transp. Policy, vol. 57, no. January, pp. 1-9, 2017. https://doi.org/10.1016/j.tranpol.2017.03.017

[55] S.A. Shaheen, M. A. Mallery, and K. J. Kingsley, "Personal vehicle sharing services in North America," Res. Transp. Bus. Manag., vol. 3, pp. 71-81, 2012. https://doi.org/10.1016/j.rtbm.2012.04.005

[56] A. Tedjasaputra and E. Sari, "Sharing Economy in Smart City Transportation Services," Proc. SEACHI 2016 Smart Cities Better Living with HCI UX - SEACHI 2016, no. May, pp. 32-35, 2016. https://doi.org/10.1145/2898365.2899800

[57] M. Van Alstyne, "Economics of B2C Sharing Platforms," ICIS 2016 Proc., pp. 1-9, 2016. ISBN:9780996683135

[58] Banerjee, S., Freund, D., \& Lykouris, T, Pricing and Optimization in Shared Vehicle Systems: An Approximation Framework. https://doi.org/10.1145/3033274.3085099, 2016 